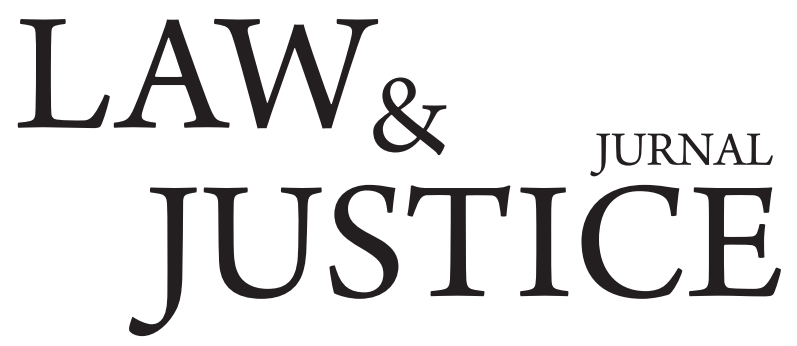

Volume 4, Nomor 1, April 2019

\title{
Pembangunan Hukum Nasional Era Industrialisasi dalam Perspektif Transendensi Pancasila Implementasi Kesejateraan Umum Pada masalah Lingkungan
}

\author{
Aprilia Stefany Leliak \\ Mahasiswa Program Studi Magister Ilmu Hukum \\ Universitas Airlangga \\ Email : apriliastefany5@gmail.com
}

\begin{abstract}
Abstrak
Di Era Industrialisasi 4.0 membawa Indonesia bahkan dunia pada pintu revolusi teknologi yang secara fundamental mengubah cara hidup. Namun dalam pembangunan hukum nasional di Era Industrialisasi saat ini tidak dapat mencegah masalah lingkungan terkait dengan penggunaan sampah plastik yang mengancam kesejahteraan kelangsungan hidup manusia belum diatur secara baik oleh Negara. Indonesia adalah Negara penyumbang sampah plastik terbesar kedua di dunia. Berdasarkan data yang dimiliki dan diperoleh dari Asosiasi Industri Plastik Indonesia (INAPLAS) dan Badan Pusat Statistik (BPS), sampah plastik di Indonesia pada saat ini mencapai 64 juta ton/ tahun. Sehingga sangat diperlukan penguatan hukum lingkungan yang berlandaskan pada pembangunan nasional berkelanjutan yang berlandaskan lingkungan hidup yang mengatur secara komprehensif untuk generasi saat ini dan generasi akan datang. Implementasi Pembangunan Hukum Nasional di Era Industrialisasi dalam Perspektif Transendensi Pancasila tidak terlepas dari hak untuk hidup yang layak pada cita-cita bersama yaitu kesejahteraan umum.
\end{abstract}

Kata Kunci: Kesejahteraan Umum, Masalah Lingkungan, Transendensi Pancasila

\section{Pendahuluan}

Di dalam Hukum (Hukum Positif) diakui sebagai pengatur, pengendali dan pengontrol seluruh kehidupan berbangsa dan bernegara, sekaligus hukum sebagai sarana pengawasan dan pemenuhan Hak Asasi manusia seluruh warga Negara Republik Indonesia. Dengan perkataan lain, bahwa dalam melaksanakan setiap kegiatan, termasuk di dalamnya melaksanakan pembangunan, khususnya pembangunan Industrialisasi haruslah berdasarkan hukum yang bertujuan untuk menignkatkan kesejahteraan dan kemakmuran rakyat Indonesia. Peningkatan kesejahteraan umum dalam hal dimaksud untuk meningkatkan kehidupan secara penuh serta membantu pencapaian integritas social Nasional yang stabil, aman dan berkeadilan social untuk seluruh rakyat Indonesia.

Tujuan untuk meningkatkan kesejhateraan dan kemakmuran rakyat, ini sesuai dengan citacita bangsa Indonesia pada saat memerdeka yaitu terhindar dari ketergantungan akan bangsa lain yang telah merampas dan ingin memiliki bangsa Indonesia akan segala kekayaan alam yang seharusnya menjadi hak dari kedaultan 
Negara Kesatuan Republik Indonesia. Harapan bangsa Indonesia yang menyatakan diri melalui kemerdekaan yaitu memiliki kebebasan untuk hidup mandiri, membangun masyarakat yang adil dan makmur di atas tanah tumpah darah Indonesia yang kaya dengan berbagai Sumber Daya Alam (SDA) dan kebhinekaan Masyarakat. Bahkan dalam Pembukaan Undang-Undang Dasar Negara Republik Indonesia merumuskan dan mengamanatkan terkait kesejahteraan Umum seluruh bangsa Indonesia merupakan kewenangan dari Pemerintah.

Dalam Era Industrialisasi sangat membawa dampak bagi kehidupan masyarakat dan kesejahteraan masyarakat. Dalam hal ini dampaknya terhadap lingkungan semakin terasa karena manusia lebih cenderung merusak lingkungan guna dan untuk mempertahankan kesejahteraan hidup masing-masing. Salah satu yang mengancam kesejahteraan hidup adalah tentang Lingkungan diperkotaan terhadap Sampah dalam hal ini yang dimaksudkan adalah Sampah Plastik.

Menurut Pasal 1 angka (1) Undang-Undang Nomor 18 Tahun 2008 Pengelolaan Sampah merumuskan dan menjabarkan Sampah adalah bagian dari sisa kegiatan sehari-hari manusia dan/atau suatu proses alam yang berbentuk padat. Sedangkan menurut Pasal 1 angka (5) di dalam Undang-Undang Nomor 18 Tahun 2008 Pengelolaan sampah juga merumuskan dan menjabarkan perihal pengelolaan sampah merupakan suatu kegiatan yang mengatur dan mengendalikan secara sistematis dan menyeluruh bahkan berkesinambungan serta meliputi bagaimana pengurangan sampah dan bagaimana penanganan sampah.

Permasalahan yang terjadi dalam Aspek mengganggu kesejateraan masyarakat dapat dilihat Dari data yang diperoleh riset Kementerian Kesehatan yang mengetahui bahwa hanya 20 persen dari total masyarakat Indonesia yang memiliki kesadarandan kepedulian terhadap kebersihan bahkan kesehatan ${ }^{1}$. Hal Ini berarti terindikasi bahwa dari kurang lebih 262 juta jiwa penduduk di Indonesia, hanya sekitar kurang lebih 52 juta penduduk di Indonesia yang memiliki

\footnotetext{
1 https://www.cnnindonesia.com/gayahidup/20180423183600-255-292946/kesadaranmasyarakat-indonesia-akan-kebersihan-masihrendah.
}

kesadaran terhadap kebersihan lingkungan sekitar dan bagaimana dampaknya terhadap kesehatan, perilaku dan kebiasaan masyarakat itu sendiri.

Hal ini dapat terlihat pada kebiasaankebiasaan kecil yang menjadi tolak ukur yaitu dari kesadaran membuang sampah di tempat umum yang sudah disedikan pemerintah hingga rajin mencuci tangan ketika melakukan aktivitas diluar rumah. Selain hal tersebut pada masyarakat perkotaan budaya memiliki pola hidup konsumtif yang sangat mempengaruhi peningkatan kualitas dan kuantitas jenis sampah plastik di Indonesia.

Indonesia merupakan negara penyumbang sampah plastik kedua di dunia dan sampah plastik yang dibuang ke laut bahkan sampah plastik sangat berbahaya. Berdasarkan data yang diperoleh dari Asosiasi Industri Plastik Indonesia (INAPLAS) dan Badan Pusat Statistik (BPS), terindikasi sampah plastik di Indonesia mencapai 64 juta ton/ tahun. Sebanyak 3,2 juta ton meruapakan sampah plastik yang dibuang ke laut. Kantong plastik yang terbuang ke lingkungan sebanyak 10 miliar per tahun atau sebanyak 85.000ton kantong plastik ${ }^{2}$.

Di Indonesia sebenarnya memiliki beberapa produk aturan perundang-undangan yang mengatur bahkan memiliki keterkaitan secara langsung terhadap pengelolaan sampah plastik. Peraturanperaturan tersebut adalah Undang-Undang Nomor 32 Tahun 2009 mengenai Perlindungan dan Pengelolaan Lingkungan Hidup di Indonesia, bahkan peraturan daerah yaitu Peraturan Gubernur Bali Nomor 97 Tahun 2018 yang mengatur Pembatasan Timbunan Sampah Plastik Sekali Pakai. Namun aturan ini hanya berlaku dan sudah ditetapkan di satu daerah dan belum ada aturan khusus yang mengatur secara komprehensif tentang Sampah Plastik di Indonesia.

Sehingga Dalam hal ini prinsip Good Enviromental Governance juga sangat diperlukan dalam pembangunan dan kesejahteraan kehidupan masyarakat Negara Kesatuan Republik Indonesia dalam pengelolaan masalah Lingkungan terkhususnya Sampah Plastik. Bahkan diperlukan juga keterlibatan yang bersinergitas dari segala sektor untuk mengelola permasalahan lingkungan sampah plastik.

\footnotetext{
$2 \mathrm{https}: / / \mathrm{megapolitan.kompas.com/}$ $\mathrm{read} / 2018 / 08 / 19 / 21151811 /$ indonesiapenyumbang-sampah-plastik-terbesar-kedua-didunia
} 


\section{Metode Penelitian}

Penelitian ini menggunakan jenis penelitian "Normatif", yaitu penelitian tertutama mengkaji bahan-bahan hukum, ketentuan-ketentuan dalam aturan aturan atau hukum positif, asas-asas hukum atau prinsip-prinsip hukum maupun doktrin hukum, guna menjawab isu hukum "Pembangunan Hukum Nasional Era Industrialisasi dalam Perspektif Transendensi Pancasila Implementasi Kesejateraan Umum Pada masalah Lingkungan". Guna melengkapi jenis penelitian untuk member arah dalam penulisan ini maka tipe penelitian bersifat "Deskripstif analstis", maksudnya bahwa hukum yang ditemukan selanjutnya dianalisis dan dibahas dengan berpatokan ahli sehingga hasilnya dapat dideskripsikan untuk membantu penarikan kesimpulan dan saran.

Di dalam penelitian hukum terdapat beberapa pendekatan dan dengan pendekatan tersebut memungkinkan peneliti mendapat informasi dari berbabgai aspek mengenai permasalahan yang sedang diteliti dan dicari jawabannya. Menurut Petter Mahmud Marzuki, pendekatanpendekatan yang digunakan dalam suatu penelitian hukum adalah: Pendekatan UndangUndang (Statute Approach), Pendekatan Kasus (Case Approach), Pendekatan Histori (Historical Approach), Pendekatan Komparatif (Comperatife Approach), dan Pendekatan Konseptual (Conseptual Approach). ${ }^{3}$

Pendekatan-Pendekatan yang digunakan dalam penelitian ini: a).Pendekatan Perundagundangan, melalui pendekatan undang-undang akan dicari aturan-aturan hukum yang berkaitan secara langsung sehingga menjadi landasan hukum mengenai Pembangunan Hukum Nasional Era Industrialisasi dalam Perspektif Transendensi Pancasila Implementasi Kesejateraan Umum Pada masalah Lingkungan. b).Pendekatan Konseptual. Pendekatan ini digunakan untuk melakukan pengkajian dan menganalisis khusus terkait dengan "Sampah Plastik" karena inti dari penelitian ini adalah Pembangunan Hukum Nasional Era Industrialisasi dalam Perspektif Transendensi Pancasila Implementasi Kesejateraan Umum Pada masalah Lingkungan. Sehingga perlu ditelaah prinsip-prinsip atau asas-asas hukum, doktrin hukum yang membahas konsep tersebut.

3 Petter Marzuki Penelitian Hukum, Prenada Median Group, Cetakan Keenam, Jakarta 2010 h.35
c).Pendekatan Kasus (Case Approach). Pendekatan ini digunakan di dalam penelitian ini adalah untuk mengkaji kasus yang bisa membuktikan apakah kesejahteraan umum pada masalah lingkungan terjadi ataukah tidak terkait dengan sampah plastik.

Penulisan ini akan dilakukan dengan penggunaan sumber aturan hukum dan bahan hukum sebagai berikut : 1) Aturan Hukum Primer, yaitu aturan-aturan hukum yang mengikat yang terdiri dari Peraturan perundangundangan yang terkait dengan judul dan masalah yaitu Undang-Undang Dasar Negara Republik Indonesia Tahun 1945, Undang-Undang No. 32 Tahun 2009 yang mengatur Perlindungan dan Pengelolaan Lingkungan Hidup, Undang-Undang Nomor 3 Tahun 2014 Tentang Perindustrian, Undang-Undang Nomor 18 Tahun 2018 tentang pengelolaan sampah, Peraturan Gubernur Bali Nomor 97 Tahun 2018 tentang Pembatasan Timbunan Sampah Plastik Sekali Pakai. 2) Bahan Hukum Sekunder merupakan bahan hukum yang memiliki penjelasan terhadap Aturan hukum primer misalnya hasil penelitian dan pendapat ahli hukum yang memiliki keterkaitan dengan masalah atau isi hukum dalam penulisan ini. 3) Bahan Hukum Tersier merupakan suatu bahan hukum yang memiliki cirri menjabarkan atau menjelaskan terhadap Aturan hukum primer dan sekunder sehingga di dalam Bahan Hukum Tersier terdiri dari media internet atau website dan kamus atau literaru atau kamus-kamus hokum.

Teknik Pengumpulan Aturan dan Bahan Hukum dalam penelitian ini dilakukan dengan studi kepustakaan yaitu dengan mengumpulkan aturan-aturan dan bahan-bahan hukum yang terkait untuk dapat memperoleh informasi yang obyektif baik dari buku, undang-undang, maupun website. Analisa Aturan dan Bahan Hukum dengan menggunakan metode menganalisis kualitatif yaitu data-data yang diperoleh kemudian dianalisis berdasarkan disiplin ilmu hukum.

\section{Hasil dan Pembahasan}

Pada Era Industrialisasi saat ini problematika tentang masalah lingkungan khususnya sampah (sampah plastik) yang menjadi penelitian pada penulisan ini terindikasi sudah sangat mengganggu Kelangsungan hidup masyarakat bahkan juga kesejahteraan masyarakat dalam artian di dalam kesehatan masyarakat dalam masalah Lingkungan. 
Sampah Plastik merupakan sisa hasil pakai yang dibuang oleh manusia yang berbahan lebih fleksibel berbahan plastik. Yul H. Harap mendefinisikan sampah merupakan salah satu bagian dari masalah lingkungan hidup yang hingga saat ini belum ada penanganan secara maksimal, khususnya yaitu pada negara-negara berkembang misalnya Indonesia, sedangkan pada kapasitas pengelolaan sampah untuk menangani permasalahan sampah terindikasi tidak memiliki keseimbangan pada produksinya yang semakin meningkat ${ }^{4}$. Untuk itu sangat diperlukan pengelolaan dan penggunaan pada masalah lingkungan terkhususnya sampah (sampah plastik) yang baik dan benar.

Pada hirarki peraturan perundang-undangan mengamanatkan Undang-Undang Dasar sebagai Landasan pertama. Sehingga sesuai dengan Ketentuan Pasal 28H ayat (1) UUD NRI Tahun 1945 yang merupakan salah satu landasan konstitusional dalam isu hukum kesejahteraan umum pada masalah lingkungan. Pasal $28 \mathrm{H}$ ayat (1) merumuskan dan mengamantkan "Setiap orang berhak sejahtera lahir dan batin, bertempat tinggal, dan mendapatkan lingkungan hidup yang baik dan sehat serta berhak memperoleh pelayanan kesehatan". Pasal tersebut mewajibkan Pemerintah merupakan pihak yang mempunyai kewenangan untuk pengelolaan masalah lingkungan misalnya Sampah. Bahkan bukan hanya pemerintah namun dibutuhkan sinergitas antara masyarakat dan dunia usaha.

Di dalam Undang-Undang Nomor 18 Tahun 2018 tentang pengelolaan sampah juga mengatur bahwa dengan pertambahan penduduk di Indonesia pada Era Indistrualisasi menimbulkan bertambahnya volume, jenis dan karakteristik sampah meningkat bahkan pengelolaan sampah selama ini belum sesuai dengan pola pengelolaan sampah berbasis lingkungan sehingga mengakibatkan dampak negatif terhadap pencemaran lingkungan terkhususnya kesejahteraan masyarakat pada kesehatan masyarakat .

Persyaratan substansial Izin Usaha Industri dalam pengelolaan lingkungan hidup tercermin

4 Waluyo, Ayub Torry Satriyo Kusumo, Rosita Candrakirana. 2012. Laporan Penelitian Hibah Bersaing dengan judul Model Pengelolaan Sampah Kota Berbasis Gender Sebagai Upaya Pengentasan Kemiskinan. Surakarta. Fakultas Hukum Universitas Sebelas Maret. h.3. pada Pasal 21 ayat (1) UU Perindustrian dan Pasal 10 ayat (3) merumuskan: melaksanakan upaya melestarikan fungsi lingkungan (lingkungan) dan larangan untuk melanggar baku mutu lingkungan (baku mutu lingkungan ambien maupun baku mutu emisi).

Produk peraturan daearah sebagai salah satu contoh acuan pada penulisan ini adalah Peraturan Gubernur Bali Nomor 97 Tahun 2018 tentang Pembatasan Timbunan Sampah Plastik Sekali Pakai dalam hal ini menjelaskan Plastik Sekali Pakai adalah segala bentuk alat/bahan yang terbuat dari atau mengandung bahan platik, lateks atau sintesis atau polyethylene, Thermplastic synthetic polymeric dan diperuntukan untuk penggunaan sekali pakai. Ada beberapa pasal yang menjadi bahan penelitian isu hukum ini adalah;

1. Dalam hal ini pada Pasal 9 Peraturan Gubernur Bali Nomor 97 Tahun 2018 menganai bagiaman Pembatasan Timbunan Sampah Plastik merumuskan dan mengamanatkan bahwa "(1). Setiap orang dan Pelaku Usaha dilarang menggunakan Plastik Sekali Pakai, (2). Lembaga Keagamaan melaksanakan pembinaan agar umatnya tidak menggunakan plastik sekali pakai dalam kegiatan keagamaan. Namun juga Pada Pasal 6 dan Pasal 7 Peraturan tersebut membatasi, melarang memproduksi, mendistribusi bahkan mewajibkan Produsen, Distributor, Pemasok, Pelaku Usaha dan Penyedia untuk menyediakan Produk pengganti Plastik Sekali Pakai.

2. Sanksi yang diamanatkan pada Pasal 22 Peraturan Gubernur Bali Nomor 97 Tahun 2018 yaitu berupa sanksi administrasi menjelaskan setaip Perangkat Daerah, unit pelaksana teknis Daerah, instansi pemerintahan lainnya, badan usaha milik daerah, Lembaga swasta, lembaga sosial, Desa Adat/Desa Pakraman, masyrakat yang melanggar ketentuan di maksud dalam Pasal 11 ayat (1) dan ayat (2) dikenakan sanksi administratif.

3. Pasal 23 Peraturan tersebut merumuskan Setiap orang, Produsen, Distributor, Pemasok, Pelaku Usaha, dan Penyedia Plastik Sekali Pakai yang melanggar ketentuan sebagaimana dimaksud dalam Pasal 6, Pasal 7 dan Pasal 9 ayat (1) dikenakan sanksi administratif. Sehingga hal demikian sangatlah membawa 
dampak untuk mengatasi permasalahan mengenai sampah plastik dan juga pengelolaan terhadap pengurangan sampah plastik di daerah Bali. Upaya yang berkaitan dengan pemberian sanksi admnistrasi merupakan penegakam hukum yang bersifat reinterpretasi dari aturan yang dibuat oleh penguasa atau pemerintah yang memiliki wewenang artinya penerapan dalam aturan hukum tersebut dengan langsung mengikat masyarakat dan pemerintah tersebut.

Peraturan di atas untuk dapat teralisasi pada segala sektor dalam pelaksanaannya pemerintah memberikan sosialisasi sehingga masyarakat dapat mengetahui dan memahai bagaimana pembatasan penggunaan pada sampah plastik, dan juga dukungan semua pihak terhadap pelaksanaan aturan tersebut, bahkan sanksi yang diberikan sangat efisien dan efektif untuk mengatur dan mengendalikan aturan tersebut.

Sehingga ada 3 hal penting yang diatur dalam Peraturan Gubernur Bali di atas yaitu Pertama Pembatasan Penimbunan Sampah Plastik Sekali Pakai dalam hal ini Kantong Plastik, Polysterina (Styrofoam) dan Sedotan Plastik. Kedua, Melarang Untuk Memproduksi, Mendistribusikan, Memasok dan Menyediakan Plastik Sekali Pakai. Ketiga, Setiap Produsen, Pemasok, Pelaku Usaha dan Penyedia Plastik Sekali pakai juga pada saat di keluarkan aturan tersebut diberi waktu menyesuaikan usahanya selama enam bulan.

Dampak dari Peraturan Gubernur tersebut saat ini di bali berhasil menurunkan penggunaan plastik sekali pakai, misalnya pelaku usaha restoran-restoran ada yang sudah tidak menyediakan sedotan atau mengganti ke bahan yang lebih ramah lingkungan seperti bambu, stainless steel. Bahkan produsen incourage untuk membawa kantong belanjaan sendiri dari rumah.

Selanjutnya dalam hal pengelolaan sampah plastik juga di butuhkan beberapa Negara yang digunakan sebagai bahan perbandingan hukum sehingga dapat memberikan suatu alternatif, memcahkan masalah hukum yang terjadi pada suatu Negara, dapat memberikan bahan-bahan yang akan digunakan untuk suatu kodifikasi hukum tersebut. Sehingga aturan-aturan hukum tentang pengelolaan dan cara mengurangi sampah plastik sehingga hal tersebut berguna untuk pengembangan dan pembaharuan hukum di Indonesia atau yang disebut dengan Unifikasi Hukum.

Di Singapura mengkampanyekan "Bring Your Own Bag" atau "Bawa Kantong anda Sendiri" sejak April 2007, dan konsumen harus mengeluarkan ekstra biaya jika ingin menggunakan kantong plastik. Hasil dari kampanye tersebut adalah di hari pertama mampu mengurangi 100.000 penggunaan kantong plastik, terjualnya 200.000 kantong non plastik yang dapat dipakai berulang kali, serta menurunnya konsumsi kantong plastik sampai dengan $60 \%$.

Afrika Selatan bersama sejumlah negara di benua itu seperti Uganda, Somalia, Rwanda, Botswana, Kenya, dan Ethiopia memberlakukan pelarangan penggunaan tas plastik. Afrika Selatan yang paling ketat memberlakukan aturan pelarangan. Sejak 2003, peritel yang kedapatan memberikan tas plastik akan didenda 100 ribu rand (setara 13.800 dolar AS) atau hukuman penjara 10 tahun. Sebelumnya, penggunaan tas plastik di negara ini mencapai 8 miliar lembar per tahun. Kini setiap pembeli membawa tas sendiri dari rumahs.

Swedia juga dianggap sebagai negara ramah sampah. Menurut data statistik Eurostat, rata-rata limbah yang dihasilkan negara-negara di Eropa sebesar 38\%, termasuk limbah plastik. Swedia adalah salah satunya yang berhasil menekan angka tersebut hingga $1 \%$, dengan teknologi pembakaran sampah $^{6}$.

Namun sayangnya pengelolaan untuk meminimalisir sampah plastik di Indonesia belum memiliki suatu aturan hukum yang secara komprehensif mengatur dan mengikat serta berisi larangan-larangan dan sanksi hukum melalui asas kemanfaatan misalnya adanya kebijakan kantong Plastik yang berbayar hal ini memberikan manfaat untuk mengendalikan masyarakat memiliki kesadaran.

Jika melakukan juga perbandingan hukum ketiga Negara tersebut yaitu dengan pendekatan micro yang berfokus kepada masalah lingkungan khususnya pengelolaan sampah plastik di Indonesia untuk mencari solusi bahkan alternatif yang dapat digunakan untuk memperbaharui hukum yang

\footnotetext{
5 http://dietkantongplastik.info/2016/10/24/19negara-di-dunia-tanpa-tas-plastik/

$6 \mathrm{https} / /$ netz.id/news/2016/10/08/00316/100707 1016/ini-5-negara-di-dunia-yang-anti-kantongplastik
} 
ada di Indonesia. Pada alternatif Negara-Negara tersebut menimbulkan berkurangnya Produksi Plastik, Plastik yang berbayar, bahkan dilarang menggunakan kantong plastik, bahkan Konsumen Incourage untuk membawah Kantong tersendiri.

Indonesia merupakan Negara penyumbang sampah plastik ke lautan terbesar kedua di dunia, sampah plastik sangat berbahaya, berdasarkan data yang diperoleh dari Asosiasi Industri Plastik Indonesia (INAPLAS) dan Badan Pusat Statistik (BPS), sampah plastik di Indonesia mencapai 64 juta ton/ tahun dimana sebanyak 3,2 juta ton merupakan sampah plastik yang dibuang ke laut, kantong plastik yang terbuang ke lingkungan sebanyak 10 milar lembar per tahun atau sebanyak 85.000 ton kantong plastik ${ }^{7}$. Berdasarkan fakta-fakta tersebut terindikasi permasalahan Lingkungan pada sampah plastik di Indonesia cukup memprihatinkan.

Sampah plastik yang terus bertambah pastinya akan menimbulkan lingkungan terganggu bahkan berdampak pada masalah kesehatan, perilaku kebiasaan membuang sampah yang tidak pada tempatnyan atau sembarangan dilakukan hampir pada semua kalangan masyarakat, separuh masyarakat masih berasumsi bahwa sampah adalah masalah etika dari masing-masing orang untuk mengontrol diri terhadap perilaku membuang sampah tersebut.

Dengan data tersebut seharusnya menyadarkan pemerintah dan semua pihak bahwa pengelolaan sampah plastik pada tidak hanya cukup dilakukan pada masing-masing daerah, Tapi seharusnya dilakukan pengelolaan secara menyeluruh di Indonesia.

Selanjutnya dengan data yang diperoleh seharusnya sudah dibatasi dengan system pengelolaan yang baik dari pemerintah guna menghindari adanya penggunaan dan peningkatan sampah plastik di Indonesia. Aturan hukum memliki funsgi control yang dapat mengendalikan perilaku hidup masyarakat secara umum. Sehingga Indonesia memerlukan suatu aturan yang khusus serta komprehensifmengenai larangan penggunaan sampah plastik yang memiliki dampak pada tingkat ketergantungan masyarkat pada plastik agar semakin berkurang karena dikendalikan

$7 \mathrm{https}: / / \mathrm{megapolitan.kompas.com/}$ $\mathrm{read} / 2018 / 08 / 19 / 21151811 /$ indonesiapenyumbang sampah-plastik-terbesar-kedua-didunia oleh suatu aturan tersebut. Hukum terhadap pengelolaan sampah plastik di Indonesia di lihat dari dua aspek yaitu sebagai suatu system nilai dan sebagai suatu aturan sosial yang mengikat semua unsur, bahkan dalam fungsi penelitian ini untuk menemukan sesuatu yang efektif fan bermanfaat terhadap permasalahan lingkungan khususnya sampah (sampah plastik) Sehingga dalam rangka mewujudkan kesejahteraan umum pada masalah Lingkungan sangat diperlukan suatu regulasi yang mengatur dan mengendalikan bahkan mengelola sampah plastik di Indonesia secara menyeluruh yaitu dengan memberlakukan suatu produk aturan yang mengikat masyarakat terhidap perliaku masyarakat untuk sampah plastik, bahkan larangan untuk memproduksi plastik di Indonesia

\section{Simpulan}

Pengaturan mengenai pengelolaan sampah plastik di Indonesia belum diatur dalam peraturan di tingkat pusat hanya pada tingkat daerah. Peraturan ditingkat pusat hanya bersifat umu terhadap pengelolaan sampah dengan pengelolaan sampah yaitu Undang-Undang No. 32 Tahun 2009 tentang Perlindungan dan Pengelolaan Lingkungan Hidup. Peraturan Gubernur Bali Nomor 97 Tahun 2018 mengenai pembatasan timbunan sampah plastik sekali pakai di dalamnya mengatur jenis dan pembatasan Plastik sekali pakai, Penggunaan produk sekali pengganti Plastik sekali pakai, bahkan Sanksi Administratif. Sehingga peraturan tersebut bersifat mengikat seluruh elemen di Bali. Perbandingan hukum dengan 3 Negara yaitu Singapura, afrika selatan dan swedia yang berhasil menurunkan jumlah sampah plastik. Sehingga perbandingan hukum tersebut memberikan solusi bahkan alternatif yang dapat digunakan untuk memperbaharui hukum yang ada di Indonesia terhadap pengurangan sampah plastik yang dapat menjadi acuan bagi Indonesia dalam membuat suatu regulasi. Di Indonesia mempunyai berbagai peraturan tentang sampah namun dalam spesifikasi sampah plastik belum diatur secara khusus dan mengikat masyarkat Indonesia secara Umum. Sehingga diperlukan Legal reform dalam artian perubahan/memperbaiki hukum atau aturan yang ada sesuai dengan masalah linggkungan pengurangan penggunaan sampah plastik sekali pakai. Misalnya dengan membuat aturan seperti penggunaan plastik sekali pakai berbayar, atau 
membatasi bahkan melarang memproduksi plastik, sehingga Konsumen Encourage untuk membawa kantong tersendiri.

\section{Daftar Pustaka.}

Petter Marzuki Penelitian Hukum, Prenada Median Group, Cetakan Keenam, Jakarta 2010.

Waluyo, Ayub Torry Satriyo Kusumo, Rosita Candrakirana. Laporan Penelitian Hibah Bersaing dengan judul Model Pengelolaan Sampah Kota Berbasis Gender Sebagai Upaya Pengentasan Kemiskinan. Surakarta. Fakultas Hukum Universitas Sebelas Maret. 2012

\section{Undang-Undang}

Undang-Undang Dasar Negara Republik Indonesia Tahun 1945

Undang-Undang No. 32 Tahun 2009 tentang Perlindungan dan Pengelolaan Lingkungan Hidup.

Undang-Undang Nomor 3 Tahun 2014 Tentang Perindustrian

Undang-Undang Nomor 18 Tahun 2018 tentang pengelolaan sampah.

Peraturan Gubernur Bali Nomor 97 Tahun 2018 tentang Pembatasan Timbunan Sampah Plastik Sekali Pakai.

\section{Internet}

https://www.cnnindonesia.com/gayahidup/20180423183600-255-292946/ kesadaran-masyarakat-indonesia-akankebersihan-masih-rendah.

https://megapolitan.kompas.com/ $\mathrm{read} / 2018 / 08 / 19 / 21151811 /$ indonesiapenyumbang-sampah-plastik-terbesarkedua-di-dunia

http://dietkantongplastik.info/2016/10/24/19negara-di-dunia-tanpa-tas-plastik/

https://netz.id/news/2016/10/08/00316/10070 71016/ini-5-negara-di-dunia-yang-antikantong-plastik

https://megapolitan.kompas.com/ $\mathrm{read} / 2018 / 08 / 19 / 21151811 /$ indonesia- penyumbang

sampah-plastik-terbesar- 